\title{
Sinema ve Dans Arasındaki İlişki: Müzikal Filmlerinde Hareket İmge
}

\begin{abstract}
Aysu Uğur*
$\ddot{O} z e t$

Sanat insanın dünyayı anlamlandırmasına ve kendini ifade etmesine yardımcı olmaktadır. Tüm sanat dalları çeşitli dönemlerde birbirinden etkilenmiştir. Sinemanın 7. Sanat olarak görülmesi diğer sanatlarla güçlü bir şekilde etkileşim halinde olmasından kaynaklıdır. Sinema görsel sanatlar içinde etkili bir yere sahiptir ve görsel-işitsel tekniklerin kullanılması açısından esnektir. Sinemanın diğer sanatlarla ilişkisinde en çok incelenen konular edebiyat, resim ve fotoğraftır. Ancak bu çalışmada dans ve sinema arasındaki ilişkiden doğan müzikal filmler, hareket-imge bağlamında incelenmiştir. Hareket, dansin ve sinemanın özünü oluşturmaktadır ve bu hareketlerin kurgusu anlam yaratmada önemlidir. Sessiz sinema döneminde Mack Sennett, Charlie Chaplin güldürülerini bedenin hareketiyle anlatmıştır ve beden sinemada bir imge haline gelmiştir. Müzikal filmlerde öne çıkan beden, müzik ve dansın etkisiyle estetik bir forma bürünmüştür, filmlerin anlatı yapısı müzikal türüne özgü değişmiştir. Deleuze sinemanın hareket bloklarından oluştuğunu söyler ve sinemayı hareketle düşünen bir sanat olarak görmektedir. Bu yaklaşımdan yola çıkarak müzikal filmlerindeki görsel imajların, sinematografik unsurlarla ve hareket ile gü̈çlendiğini söylemek mümkündür. Bu bağlamda Damien Chazelle'in yönettiği "La la land" (2016) filminin örneklem olarak seçilmesinde düşsel dünyayı kuran hareket-imgeler etkili olmuştur. Film analizi yöntemiyle filmdeki hareket imajlar incelenmiş ve müzikal türünün kendine özgü kodları açıklanmıştır.
\end{abstract}

Anahtar Sözcükler: Müzikal Film, Hareket-İmge, Dans

ORCID ID : 0000-0003-0671-2909

E-mail : aysuugur6@gmail.com

DOI: 10.31122/sinefilozofi.495107

Geliş Tarihi - Recieved: 11.12.2018

Kabul Tarihi - Accepted: 15.02.2019 


\title{
Relationship Between Cinema and Dance : The Movement İmage İn Musical Movies
}

\author{
Aysu Uğur*
}

\begin{abstract}
Art helps people to make sense of the world and to express oneself. All arts are influenced by each other at various times. Cinema is seen as being sourced from the 7 th Art interact strongly with other arts. Cinema has an effective place in the visual arts and flexible in terms of the use of audio-visiual techniques. The most studied topics relation to other art and cinema; literature, painting and photography. However, in this study, the musical film born of the relationship between dance and cinema are examinate in the context of movement image. Movement is the essence of dance and cinema and the fiction of these movements is important to create meaning. During the silent cinema Mack Sennet, Charlie Chaplin described their laugh with the movement of the body and the body has become an image in cinema. The prominent body in musical films has become aesthetic with the influence of music and dance, the narrative structure of films has changed. Deleuze says that cinema is made up motion blocks and he regards cinema as an art that thinks in action. In this context Damien Chazelle's "La la land" (2016) was chosen as the sample of the film and the movements that established the imaginary world became influential. Movie images on film were analyzed by film analysis method.
\end{abstract}

Keywords: Musical Film, Motion-Image, Dans

ORCID ID : 0000-0003-0671-2909

E-mail : aysuugur6@gmail.com

DOI: $10.31122 /$ sinefilozofi.495107

Recieved - Geliş Tarihi: 11.12.2018

Accepted - Kabul Tarihi: 15.02.2019 


\section{Giriş}

İnsan toplumsal bir varlıktır ve sanat insanlara deneyimlediği veya deneyimlemediği duyguları göstermektedir. Böylelikle insan toplum içinde yaşanan farklı durumları sanat aracılığıyla deneyimlemektedir. "İnsanın çoğalma, bütünlenme isteği de gösteriyor ki bireyden ötede bir şeydir insan. Bütünlüğge ancak başkalarında kendi yaşantısı olabilecek yaşantıları görüp onları kendinin kılmakla varabileceğini sezer "(Fisher, 1990: 6). Bu yüzden sanat insanlar için bütünleştirici bir özelliğe sahiptir ve insanların kendilerini farklı yollarla ifade etme biçimidir. Etkili bir sanat dalı olan sinema duygulara hitap ederek empati özelliğimizi açığa çıkarır ve duygulanım yaratır. Badiou'ya göre sinema bir kitle sanatıdır.

Badiou'nun sinemanın kitle sanatı olmasının nedenleri olarak saydığı hususları şu şekilde özetleyebiliriz: sinemanın aynı zamanda yaratılıp pek çok insan tarafindan tüketilmesi, bu itibariyle bir başyapıt olması, daha kolay özdeşleşmeye imkân veren görsel imajların varlığı ve zamanı algilanabilir hale getirmesi (Öztürk, 2018: 201).

Gustave Le Bon Kitleler Psikolojisi adlı kitabında kitle tabirinin psikoloji açısından daha farklı anlamda kullanıldığını belirtir. Ona göre bilinen anlamda kitle kavramı rastgele fertler topluluğunu ifade ederken, psikolojide kitleler yeni bir karakter kazanan, kolektif hislere sahip, bilinçli şahsiyetleri ortadan kalkan kişiler olarak ifade edilir (Le Bon, 2014). Gustave Le Bon kitlelerin sadece hayalleriyle düşünebildiklerini ve hayalleri aracılığıyla tesir altında bulundurulabildiklerini belirtir.

Yalnız hayaller onlarn korkutur veya kendine çeker ve onlarm eylemleri üzerinde tesirli olur. Bu sebeple, hayali en açık bir şekilde canlandıran tiyatro oyunları, kalabalıklar üzerinde büyük bir tesir uyandırır. (...) Halkın hayal gücüne en çok tesir eden olgu tiyatrodur. Bütün salon aynı zamanda aynı heyecanları yaşar. Bu heyecanların fiil durumuna gelmemesinin sebebi, en bilinçsiz seyircinin bile hayallere mağlup olduğunu, hayallerden ibaret maceralara güldüğünü veya ağladığıı bilmemesidir (Le Bon, 2014: 66-67).

Sinemanın tiyatroyla olan ilişkisi yarattığı kolektif duygulardan kaynaklıdır. "Tiyatro ile sinema arasında geçmişten elde edilen bazı verilerin toplanması sonucunda bir bağ oluşturularak "filmleştirilmiş tiyatro olgusuna erişilmiştir" (Bazin, 2013: 85). Bazin tiyatronun sinema üzerindeki etkisinin büyük olduğunu ancak sinemanın uzam açısından büyük bir hareket serbestliğine sahip olmasını ayırt edici olarak görür. İşte bu hareket serbestliği ve teknolojik gelişmeler sinemayı daha büyük kitlelere ulaştırmış ve hareket, dans ve sinemayı kesiştirecek bir öge haline gelmiştir.

Çalışmada etkileşim halinde olan sinema ve dans arasındaki ilişki incelenmiş ve iki sanat dalından beslenen müzikal filmlerin kodları açıklanmıştır. Deleuze'ün hareket-imge kavramı müzikal tür bağlamında incelenmiştir. Müzikal filmlerin başat özelliği harekete dayanmasıdır. Örneklem olarak Damien Chazelle'in müzikal türüne geri dönüş olarak nitelendirilen La La Land filmi seçilmiş ve filmdeki sinematik imajlar hareket-imge ile temellenmiştir. Film analizi yöntemiyle La La Land filmindeki hareket imajlar ve müzikal türüne ait sinematik kodlar incelenmiştir. 


\section{Sinema - Dans Arasındaki İlişki}

"Sinema, dünyanın belli bir görünümünün yansımasıdır ve insanoğlunun teknik uygarlığı ile doğrudan ilgili olarak gelişmektedir"(Bazin, 2013: 71). Sinema ilk başta eğlence ve endüstri aracı olarak görülmüştür. 1900'lü yıllarda Amerikan yıldız stüdyo sistemiyle ticari filmler üretilmiş ve Hollywood sinema endüstrisi büyük bir güç haline gelmiştir. 1920'li yıllardan itibaren Avrupa'da başlayan sinema akımlarıyla da birlikte sinema bir sanat dalı olarak görülmüştür. Fransız Yeni Dalgası etrafında şekillenen Auteur kuramı yönetmenin özgünlüğünü vurgulamış ve yönetmenin filmlerdeki rolünü ortaya koymuştur. Yaratıcı yönetmen politikası 1950'de Fransa'da yayınlanan "Cahiers du Cinema" dergisinin film eleştirilerinden doğmuştur. Chaiers du Cinema dergisinin genç eleştirmenleri Truffaut ve Godard Amerikan filmlerini izleyip filmler arasında karşılaştırma yaparak yönetmenin özgün ve yaratıcı imajlarını ortaya çıkarmıştır.

Sanatsal açıdan sinemanın estetik ve teknik yönü, diğer sanat dallarıyla ilişkisinden beslenmektedir. Sinema diğer sanat dalları ile -edebiyat, müzik, resim, fotoğraf, dans- etkileşim halindedir. Andre Bazin fotoğrafın yaratıcı gücünün olduğunu ve fotoğrafın ortak oluşumları paylaştığını belirtmiştir. Aynı şekilde Bazin sinemayı, edebiyat ve tiyatro dallarının mirasçısı olarak görmüştür. Sinemanın diğer sanat dallarıyla olan ilişkisi araştırıldığında öncelikle edebiyat, resim ve fotoğraf dalları incelenmiştir. 1930'lu yıllarda sinemaya sesin ve rengin gelmesi sinematografiyi zenginleştirmiştir. Ses ile birlikte filmlerde kullanılan müziğin önemi daha çok artmış ve müzikal türünün oluşmasına zemin hazırlamıştır. Sinemada ses olgusu anlatının desteklenmesi açısından önemlidir. " Filmlerin işitsel evreni, müzik, konuşma ve ses efektleri olarak üç temel bileşenden oluşur. Bu bileşenlerle bilinçli şekilde oluşturulmuş ses tasarımı, filmlerin başarısı için şart olan asal öğelerden biri konumundadır" (Sözen, 2017: 477). Ses ile birlikte filmlerde kullanılan müzik ayrı bir öneme sahip olmuştur. Ali Cemalcılar film için bestelenen ve kullanılan müzik türlerini iki biçimde sınıflandırmış, bu türleri "gerçek" ve "işlevsel" müzik olarak ayırmıştır. Cemalcılar, gerçek müziği, müzikallerde ve danslarda kullanılan genel atmosferi denetleyen müzik olarak tanımlamıştır (Cemalcılar, 1993: 73).

19. yüzyılın en önemli Fransız şairlerinden Charles Baudelaire'e göre (9 Nisan 1821-31 Ağustos 1867) dans, müzikte saklı olan tüm gizemi ortaya çıkarmaktadır ve insan olmanın değerini göstermektedir. "Dans, kolların ve bacakların şiiridir" (Baudelaire). Sinema ve dans arasındaki ilişki ikisinin de dinamik sanatlar olmasından kaynaklıdır. Sinema ve dans durağanlık yerine devinim temellidir. Sinema görsel imajların hareketle buluştuğu yerde anlam kazanmaktadır. Beyaz perdede birbiri ardına eklenen görüntüler de bir hareket içindedir ve onların anlamları seyirciyi düşünmeye, sorgulamaya itmektedir. Dans bedenle duygu ve düşünceleri aktarmaktadır. Kimi zaman bir mutluluk göstergesi olarak hareket eden beden kimi zaman da seyirciyi rahatsız ederek ya da içinde bulunduğu durumu betimleyerek izleyenleri düşünmeye itmektedir. Beden genellikle müzikal filmlerde hoş duyguları yansıtan ve seyirciyi rahatsız etmeyen türde kullanılmıştır.

Müzikal filmler, müzik ve dansın öykü anlatımında öne çıtığı, sinemanın teknik ögeleriyle de zenginleştiği bir türdür. Film endüstrisine yön veren Hollywood stüdyo sistemi müzikal filmlerin üretilmesinde etkili olmuştur. İlk yıllarda bazı düşünürler tarafından müzikal filmleri eleştirilmiştir. Müzikaldeki gösterişli dekorlar, hareketli danslar ve şarkılar izleyenler için kaçış filmi olarak görülmüştür. Müzikal filmlere gelen eleştirilerden bir diğeri de müzikal filmlerin bir derdinin olmadığı, sadece eğlence amacı güttükleri düşüncesidir. 
Sinemada ilk sesli film olarak "The Jazz Singer" (Caz Şarkıcısı, Alan Crosland, 1927) filmi kabul edilmiştir. İlk müzikal film ise "The Broadway Melody"dir (Broadway Melodisi, Harry Beaumont 1929). 1930'larda Hollywood müzikalleri Warner Stüdyolarında yapılmaya başlamıştır. "Warner'ın otuzlarda yaptığı müzikallerde gerçek dünyayla eğlence dünyası iç içe geçmiştir" (Abisel, 1995: 196). Otuzlu yıllarda kamera kullanımıyla öne çıkan Busby Berkeley, filmde dansın kameraya göre düzenlenmesini söylemiştir. Otuzlu yılların sonunda müzikal üretimi İkinci Dünya Savaşı'na rağmen devam etmiştir. Müzikaller 40 ve 50'li yıllarında altın çağını yaşamıştır. Bu dönemde müzikallere ayrılan bütçe artmış ve müzikal üretimi için birden çok stüdyo hazırlanmıştır. 70'li yıllarda müzikal filmlerin üretimi ve filmlere olan ilgi azalmaya başlamıştır. Ancak günümüzde müzikal filmlere geri dönüş olarak görülen filmler de üretilmektedir. Bu çalışmada son yıllarda öne çıan "La La Land " (Aşıklar Şehri, Damien Chazelle) filmi müzikalin sihirli dünyasını hareket- imajlarla yeniden kurmaktadır. Sinema ve dans arasındaki en önemli bağ devinimin yarattığı estetiktir. Hareket, dansın ve sinemanın özünü oluşturan başat bir öge haline gelmiştir.

\section{Müzikal Filmlerinde Hareket - İmge}

Sinema felsefesi üzerine düşünen ve sinemanın imajlarla düşünce ürettiği ileri süren Gilles Deleuze, çalışmalarını Bergson'un hareket üzerine düşünceleri doğrultusunda ilerletmiştir. Bergson'a göre hareket şimdiki anı yansıtmaktadır. Deleuze sinematik imgeyi diğer sanat dallarındaki imgelerde farklı bir yere koymuştur. Zihinde beliren ve durağan olan imgeler sinema ile hareket kazanarak şimdiki anı oluşturmaktadır. Deleuze'e göre birbirinden farklı imgeler mevcuttur ancak imge hareket ile anlam kazanmaktadır. İmgeleri algılayan kişiyi yani özneyi "canlı imge" olarak adlandırmıştır. Canlı imge ile hareket imgeyi buluşturan ise sinemadir.

Deleuze sinemasal imgenin hareketliliğine vurgu yapmış ve sinemanın imge kavramını somutlaştırdığını ileri sürmüştür. Ona göre hareket süredeki ya da bütündeki bir değişimi ifade eder (Deleuze, 2014). Düşünce ve değişim Deleuze için önemli bir kavramdır. Sinemayla felsefe arasındaki etkileşim ikisinin de düşünce temelli olmasıdır. Felsefe kavramlarla düşünceyi aktarırken sinema görsel imajlarla düşünceleri yaratır. Bu bağlamda sinema zihinsel ve yaratıcı bir süreçtir.

Deleuze sinemadaki hareket imgeyi oluşturan ögelerin kamera hareketleri ve montaj olduğunu söyler. Ona göre hareket imgeler her seferinde farklı kompozisyonlarda olurlar. Deleuze hareket imgeyi alg1 imge, eylem imge ve duygulanım imgenin birleşimi olarak tanımlamaktadır. İnsan dış dünyayı algılarken kendi ilgisine ve ihtiyacına göre imgeleri algılamaktadır. Ancak sinemada kamera bizim algılarımıza hitap edecek şekilde imgeleri kullanmaktadır. Filmdeki karakterin kendini tanıması ve bulunduğu mekânı algılaması alg1 eyleme örnek olarak verilebilir. Eylem imge ise özne ve nesnenin arasındaki etki-tepki ilişkisidir. Deleuze eylem imgenin orta plan çekim ölçeğiyle yansıtıldığını söylemektedir (2014: 100). Eylem imge kameranın veya karakterin durağanlıktan çıkıp hareket etmesi olarak da tanımlanabilir. Sinemadaki imajlar önce seyirci tarafından algılanır ve bu alg1 sonucunda bir duygulanım oluşur. İnsan beyninin algı sürecinde olduğu gibi sinemadaki süreç de böyle işlemektedir. "Hareket imgenin son dönüşümüdür duygulanım imge" (Deleuze, 2014: 94).

Duygulara hitap eden müzikal filmleri Deleuze'ün bahsettiği hareket imge süreçlerinin 
hepsini kapsamaktadır. Müzikal filmlerindeki gösterişli filmsel imgeler, hareketli danslar sinemada hareket imgenin göze çarpan unsurlarıdır. Müzikallerin kaçış filmi olarak nitelendirilmesine neden olan özdeşleşmeyi sağlaması ve üst düzeyde duygulara hitap etme özelliği de hareket- imgenin kurulması açısından önemlidir.

Müzikal filmlerde müzik ve dans öykü anlatımını destekleyen unsurlardır. Müzikal filmler ilk yıllarda seyircilerin güzel vakit geçirmeleri için üretilmiştir. Nilgün Abisel müzikal filmlerinin gelişimini şöyle tanımlamaktadır:

Müzikallerin arkasında, eylemi, hareketleri ve müziği birlikte kullanan tüm sahne gösterilerinin -melodram, vodvil, sirk, müzikhol, varyete, kabare, sahne müzikali - oluşturduğu güçlü bir gelenek vardır. Ayrıca, yirminci yüzyılın ilk yillarında büyük ilgi gören spectacle'larm sahne düzenlemesi ile tekniklerde yaptıkları değişiklikler, tiyatroda büyük dekorların ve kalabalık oyuncu kadrolarmın yönetilmesine olanak vermiştir. Böylece, zengin, süslü ve pahah Broadway müzikalleri, Amerikan burjuva kültürünün önemli bir parçası haline gelmiş; Avrupa'nın "ciddiyet"inden kurtulmuş ve popülerlik üzerine kurulmuş bir gösteri tarzı gelişmiştir (Abisel, 1995: 209).

Müzikal filmlerinin duygulanım yaratmadaki etkisi anlatı ve mizansen yapısından kaynaklanmaktadır. Öykü aşk ilişkileri üzerinden kurulur ve genellikle mutlu sonla biter. Sinemada mizansen; dekor, kostüm, makyaj veaydınlatmadan oluşmaktadır. Müzikal filmlerde mizansen, türün kendine özgü kodları arasındadır, dekor ve mekânlar çeşitlilik gösterir. Abisel kentlerde, tiyatro binalarının, stüdyoların, işlek ve 1şıklarla donatılmış caddelerinin, apartman dairelerinin müzikaller için en çok kullanılan mekânlar olduğunu belirtir (1995: 218). Oyuncuların ve dansçıların canlandırdığı roller belli bir toplumsal statüyü işaret eder. Böylece müzikallerdeki toplumsal sinıflara ait kültürel imgeler dekorların kullanımında önemlidir. Müzikallerin zengin dünyasında alt tabakadan kişiler yer almamaktadır. Sanatla ilişkisi olan Paris'e özgü giyim tarzı ve yüksek kültürün temsil ettiği mekânlar filmin öyküsünü desteklemektedir. Kostüm ve makyajlar müzikalin büyülü dünyasını destekleyecek nitelikte renkli ve canlıdır. Aynı şekilde aydınlatma, düşsel dünyanın kurulması açısından öne çıkar, net ve canlı ekran seyircinin estetik algısı açısından önemlidir. Çünkü müzik, renk, ses gibi sinematografik unsurlar seyirciyi hissedeceği duyguya hazırlamaktadır. Gerilim dolu bir müzik bize kötü bir şeyler olacağının habercisidir ve korku, gerilim türünde sıkça kullanılır. Müzikallerde durumu anlatan müzikler, canlı renkler, hazırlanmış profesyonel koreografiler seyircinin olayın akışına kapılmasına yardımcı olmaktadır.

Toplumsal hayattaki iletişimde önemli bir unsur olan beden politikaları kişinin ruh hali ve kişiliği hakkında ipuçları vermektedir. Giyim, jest ve mimikler, bedenin duruşu bireyin içinde bulunduğu durumu yansıtmaktadır. Sinema filmleri de görsel bir sanat olduğu için karakterlerin durumu diyaloglarla aktarıldığı gibi beden politikalarıla da aktarılabilir. Sessiz sinema döneminde beden hareketleriyle öne çıkan Mack Sennett, kaba güldürülerini tempolu hareketleriyle tamamlamıştır. Mack Sennet'ın filmlerinde insanlar mekanik bir robot gibidir ve fiziksel özellikleri ayırt edilebilir tarzdadır. Beden ve kamera hareketini bir arada öne çıkaran Sennett kameranın ve kurgunun sağladığı imkânları kullanarak, yavaşlatılmış ve hızlandırılmış hareketin yanı sıra geriye harekete de yer vermiştir (Abisel, 2014). Beden hareketleriyle sinemada bir kült haline gelen Şarlo tiplemesiyle öne çıkan Charlie Chaplin de zikzaklı yürüyüşü, hareketleri ve mimikleriyle öne çıkmıştır. Chaplin fiziksel özellikleriyle dikkat çeken tiplemelerini komedi türünün kodlarına uygulayarak kullanmıştır. Müzikallerde öne çıkan beden, dansın yaratmış olduğu hareketle daha da büyük role sahiptir. Çünkü 
hareket, estetik bir sanat dalıyla birleşerek müzikal filmlerini doğurmuştur.

Sinemada gerçeklik ve temsil her zaman tartışılan bir konu olmuştur. Gerçekçiliği savunan film kuramcıları ve yönetmenleri için kamera kaydetme aracı olarak görülmüş ve olanı olduğu gibi aktarma amacı gütmüşlerdir. Gerçekçiler kurguyu, ses efektlerini, özel aydınlatmaları reddetmişlerdir.

Andre Bazin sinemanın saf bir sanat olmadığını ileri sürer. Fotoğrafik imgenin gerçekçiliğine inanan Bazin, gerçekçi filmlere daha çok ilgi duymuştur. Bazin için algısal gerçeklik mekânsal gerçekliktir. Biçimciler ise sinemanın bir dil yetisine sahip olduğu fikrini montajla pekiştirmiştir. Montaj sinema dili yaratmak ve gerçeği esnetmek bakımından önemlidir. Birbiri ardına sıralanan görüntüler düşünceyi yansıtmaktaki en iyi araçtır. Biçimciler sinemanın bir sanat olarak görülmesinde montajın etkili bir yeri olduğunu söylediler ve bu diyalektik sürece önem verdiler. Sinema, var olan gerçekliği sinematografik unsurlarla yeniden kurar ve zamanda sıçramalar yapar. Resim veya fotoğraf gibi sabit anlatı yapısına sahip değildir. Bu yüzden sinemanın saf gerçeği yansıtmadı̆̆ı, imajlar yaratan bir sanat dalı olduğu düşüncesi de tartışılmıştır.

Hareket imge üzerine yapılan çalışmalarda genellikle hareket imgenin ana akım sinemada büyük yer tuttuğu vurgulanmıştır. Ana akım sineması sinematografik teknikleri güçlü bir şekilde kullanmakta ve seyircinin duygusal tepkilerini hedef almaktadır. Bu doğrultuda montajdaki hızlı kesmeler, sahneler arası hızlı geçiş, aksiyon, canlı renkler ön plana çıkmaktadır. Seyirciyi olayın içine çekerek anlatıya ortak eden ana akım sinemada hareket imajlar hız ve duygusal tepki üzerine kuruludur. Ancak bu hareket imajların düşünce üretmediğianlamina gelmemektedir. Deleuzehareketimajın sinemadakimizaman propaganda aracı olarak da kullanılmasını eleştirmiştir. Hareket imge daha çok psikolojik ve duygusal etkiler bırakmaktadır. Bu doğrultuda müzikallerin büyülü dünyasında hareket imgeler dekor, kostüm, çerçeveleme, kamera hareketi, kurgu ve dans ile bir bütün oluşturmaktadır.

\begin{abstract}
Filmler, içinde yaşadığımız dünyada hayatın içi ve dışı arasında bir düş gibidir. Gerçek dünyadaki hareketin ve zamanın aynısın sinematik evrende gördü̆̈̈̈müzde, neyin düş, neyin gerçek olduğunu sormaya başları. Sinematik eorendeki hareket-zaman blokları, bizlere gerçek-düş ayrımının nerede başlayıp nerede bittiğine dair sorular sordurtur (Öztürk, 2018: 23).
\end{abstract}

Sinema düşler yaratmanın en iyi aracıdır. Seyirci üretilen görsel düşlere eşlik etmektedir. Özellikle müzikal filmler düşsel dünyanın inşasında etkilidir. Öztürk müzikal filmlerindeki dansları "dünya hareketi" olarak görmektedir (Öztürk, 2018 : 364). Deleuze'ün "ima edilmiş düş" kavramı müzikal filmlerinde sergilenen dansları da kapsamaktadır. Bu danslar düş dünyasının vurgulanması ve hareketin gösterilmesi açısından önemlidir. Öztürk ses, renk, 1şık, müzik, dans gibi ögelerin ima edilmiş düşte aktif görev üstlendiğini belirtmiştir. Bu düşsel dünyanın kurulmasında sinemanın da özünde yatan hareket önemlidir.

\title{
"La La Land" Filmindeki Büyülü Dünyanın İnşası
}

Türkçeye Âşıklar Şehri olarak çevrilen La La Land filmi 2016 yapımı müzikal bir filmdir. Filmin yönetmeni Damien Chazelle, başrol oyuncuları Emma Stone ve Ryan Gosling'tir. Film 2017 Oscar ödüllerinde en iyi kadın oyuncu, en iyi yönetmen, en iyi prodüksiyon tasarımı, en iyi sinematografi, en iyi film müziği ve en iyi orijinal şarkı ödüllerini kazanmıştır. Filmin konusu, ünlü bir yıldız olmak isteyen Mia ile müzisyen Sebastian arasındaki aşktır. 
Filmin giriş sekansında Los Angeles trafiğine takılan arabalar gösterilir. Kamera uzunca bir süre arabaların içinden geçerek bir kadının arabasına yaklaşır ve dans başlar. Kadın arabadan inerek şarkı söyler, dans eder ve diğer arabalardaki insanlar da ona katılır. Kamera hareketli şekilde şarkı söyleyen insanları takip etmekte ve adeta rüzgâr gibi aralarından geçmektedir. Trafikteki sıkıcı ortam bir anda eğlence mekânına dönüşürken gri renkler yerine canlı renkteki arabalar ve kıyafetler ön plana çıkmaktadır. Somut mekân dans eden ve şarkı söyleyen insanlarla soyut ve hayali bir mekâna dönüşmektedir. Mekânlar toplumsal ilişkileri yansıtan ve insanların anlamlandırdığı yerlerdir. Trafikle sıkışık olan bu yol, dansçılar tarafından yeniden üretilmekte ve farklı şekilde anlamlandırılmaktadır. Bu sekansta hareket imge dansçıların senkronize hareketleriyle ve aktüel kameranın takibiyle sağlanmaktadır. Dansın ardından coşkulu müzik yerini sabit, duran trafiğge bırakır ve kamera başrol Sebastian'a doğru ilerler.

Mia bir kafede çalışmaktadır ve hayali oyuncu olmaktır. Katıldığı oyuncu seçmesi iyi geçmez ve arkadaşları onu bir davete gitmeye ikna etmeye çalışmaktadır. Evde başlayan dans sekansıyla kamera odalar arasında süzülüp dolaşmaktadır. Karakterlerin ve kameranın hareketi Deleuze'ün "eylem imge" kavramına örnektir. Müzikal filmlerindeki temel kodlardan biri olan uzun plan çekimleri bu filmde de yoğunluktadır. Hızlı kesmelerden ziyade tek plan çekimler öne çıkmaktadır. Kullanılan şarkı, karakterlerin içinde bulunduğu durumu betimleyecek tarzdadır ve müzikal türünün gösterişli dünyasını yansıtan canlı renkler, estetik danslar Mia ve arkadaşlarının şarkı söylediği bu sekansta göze çarpmaktadır. Partiden sıkılan Mia bir anlığına tek başına şarkı söylemeye başlar ve etrafındaki her şey kaybolmaktadır. Mia kendisine müzikle bir kaçış noktası açmakta ve an'da kırılmalar yaratmaktadır.

Filmdeki hareket imgeler genel anlatıyı destekleyecek şekilde devam etmektedir. Film klasik anlatı yapısı ile ilerlemektedir. İlk olarak Mia'nın işi ve hayalleri aktarılmakta, bir sonraki

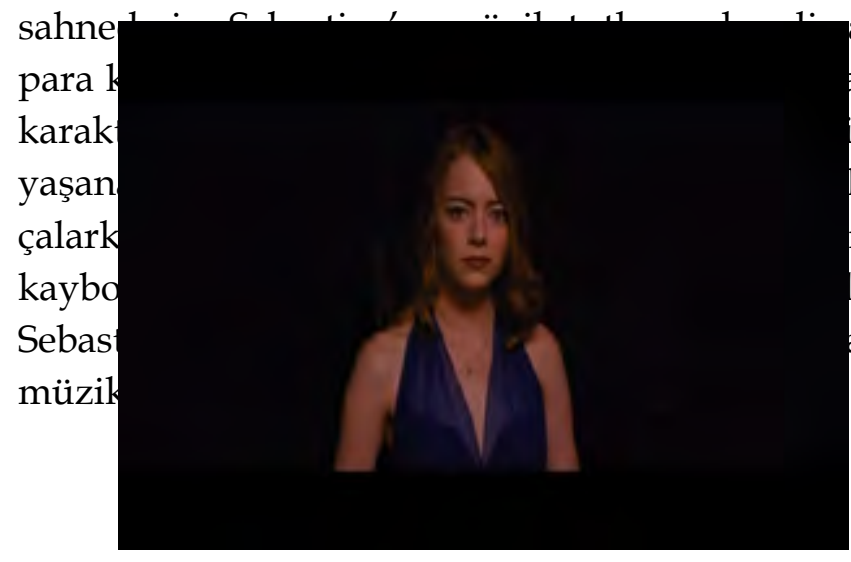

Görsel 1: Mia

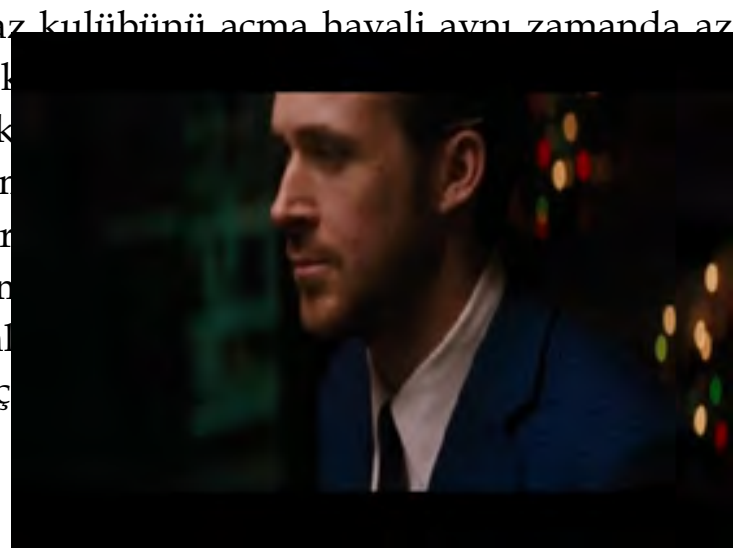

Görsel 2: Sebastian

Mia ve Sebastian'ın restorandaki karşılaşmasında Sebastian'ın çaldığı müzik ikisinde ortak bir duygu yaratmaktadır. Kamera Mia ve Sebastian'ın yüzlerini yakın planda çekmiştir. Deleüze'ün hareket imgenin evresi olarak gördüğ̈ü duygulanım imgede yakın plan ve yüz önemlidir. Yüz duyguların yansıtılması açısından etkili bir imgedir. Mia ve Sebastian'ın bakışlarından birbirlerini fark ettikleri anlaşılmaktadır. Ancak Sebastian canı sıkkın olduğu için Mia ile konuşmadan oradan uzaklaşmıştır. Mia Sebastian' dan beklediği ilgiyi görememektedir.

Karşılaşmalarının ardından biraz zaman geçtikten sonra yolları bir partide tekrar kesişmektedir. Mia'nın gittiği partide Sebastian müzik grubuyla birlikte sahneye çıkmıştır. 
Orada konuşmaya başlarlar ve birlikte boş bir sokakta yürürler. Yol kenarında dans ettikleri sahnede manzaradaki mavi ve pembe tonlar masalsı bir görünüm yaratmaktadır. Mia ve Sebastian şarkı söylemeye ve dans etmeye başlamaktadır. Şarkı sözleri birbirlerinden hoşlanmadıklarını betimlemektedir. Manzara ve arka fon müziği bir masalı andırsa da şarkı sözleri tam tersini söyleyerek gerçeği saklayan bir araç olarak karşımıza çıkmaktadır. Çünkü Mia ve Sebastian senkronize bir şekilde dans etmeye başlarlar ve bu uyum müzik, renk, hareket gibi unsurlarla pekişmektedir. Hareket imge unsurları karakterlerin gerçek duyguları hakkında ipucu vermektedir. Kamera sürekli Mia ve Sebastian'1 takip etmekte ve uzun hareketli planlarla dansın devamlılığını aktarmaktadır. Müzik ve ritim atılan her adımı desteklemektedir. Deleuze'un "eylem imge" kavramı burada kendini göstermektedir. Kameranın hareketi ve beden hareketi eylemi başlatmıştır. Şarkı sözleri bu noktada kaybolmakta sadece beden hareketleriyle gerçek duygular anlatılmaktadır. Telefonun çalmasıyla dansla kurulan soyut dünya yerini gerçekliğe bırakmıştır.

Görüşmeye başlayan Sebastian ve Mia hayallerini birbirleriyle paylaşmışlar ve aralarındaki bu aşk, müzik ve dansla pekişmiştir. Dans ile birlikte kendilerine bir dünya yaratmışlardır. Birliktelik süreçleri farklı zaman ve mekânların birleşimiyle gösterilmekte ve zaman, mekân sıçramaları yapılmaktadır. Hızlı kurgu geçişleri sayesinde karakterlerin geçirdikleri zaman filmsel zamanla ayrışmaktadır.

Gerçek yaşamın maddi zorluğu onların hayalleriyle farklı noktadadır. Sebastian kendi caz kulübünü açmak için arkadaşının iş teklifini kabul eder ve grupta piyanist olarak çalmaya başlar. Sebastian artık ünlü bir müzisyen olmuştur, yoğun iş temposundan Mia'ya vakit ayıramamıştır. Mia ile olan ilişkisi artık bozulmaya başlamıştır. Mia ve Sebastian hayallerinin peşinden giderken yollarını ayırmak zorunda kalmış, ikisi de farklı hayatlarda sevdikleri mesleği yapmaya devam etmişlerdir. Filmin anlatısı bu noktada klasik müzikal filmin kodlarını yıkmaktadır. Müzikal filmlerindeki aşk hikâyeleri mutlu sonla bitmektedir. Beklenen mutlu son Sebastian ve Mia'nın hayaliyle resmedilmiştir. Kurulan düş dünyasında her şey mutlu sona bir hazırlıktır, masal gibi bir hayattır. Dans ve müzik alternatif bir mutlu son hayalini betimlemektedir. Romantik müzik, sıcak renkler, birbirine dönük bedenler, jest ve mimikler hayal dünyasını resmetmektedir. Ancak gerçek mekân ve zaman kurulan hayali durdurur. Mia ve Sebastian' 1 n hayatları farklıdır. Film bir yandan diegetik anlatısında müzikal kodlarını kırarken, diğer yandan kahramanların hayal dünyasında müzikal kodlarını yeniden kurmaktadır. Bu yüzden müzik ve dans hayallerle özdeşleşmiş olarak yansitılmaktadır.

Filmin son sekansında Mia ve Sebastian dönüp birbirlerine bakmaktadır. Bu bakış bir veda bakışı niteliğindedir ancak ikisinin de yüzlerinde belli belirsiz gülümseme vardır. Yine bu sahnede de duygulanım imge aracı olan yakın plan çekimi önemli yer tutmaktadır.

Filmdeki hareket imaj, bedenin estetik hareketi, kamera açıları, müzik ve montajla sağlanmıştır. Dans sekansları öykünün anlatılmasında büyük rol oynamıştır. Deleuze bedenin bir imge olduğunu ve bedenin eylemler kümesi olduğunu söyler. Düşsel dünya şarkının ve dansın başlamasıyla kurulmuştur. Şarkı sözleri ve kullanılan müzik olayın atmosferine uygunluk göstermiştir. Filmde kullanılan renkler büyülü dünyanın inşasında önemlidir. Karakterler düş kurmaya başladıklarında etraflarındaki kişiler ve nesneler kaybolmaktadır. Sadece aşkı yaşayan iki karakter üzerinde 1şık toplanır, gerçek dünyaya dönüldügüünde ise tüm 1şıklar açılır ve gerçeklik kaldığı yerden devam etmektedir. La la land, müzikal filmin kendine özgü sinematografik unsurlarını büyük ölçüde kullanmıştır. 


\section{Sonuç}

Duygu, düşünce ve hayalleri farklı formlarla yansitan sanat dallarının birbirleriyle etkileşimi sinemada yeni kavramların tanımlanmasında etkili olmuştur. Fotoğrafın durağanlığı yıkan, zamansız ve mekânsız olma özelliği taşıyan ve diğer sanat dallarını içinde barındıran sinema, yarattığı düşünsel ve görsel dünya ile kitleleri etkilemeyi başarmıştır. Hareket sinemanın ilk yıllarındaki komedi filmlerine öncülük etmiş, sessiz sinema döneminde bedenin hareketi yeni bir forma bürünmüştür. Hareket, Rus Biçimcilerin sinemayı düşünce üretme ve yayma aracı olarak görmesine yardımcı olmuş ve filmin montajla farklı bir boyuta geldiğini savunmuşlardır. "Hareket imgesine dayalı sinemanın en belirgin özelliği olan ani etki, izleyiciyi, bir içsel yaratım sürecine sürükler. Bu yaratım süreci de izleyiciyi çarpıcı montajın sunduğu anların birbirini takip etmesine bağımlı kılar"' (Sütcü, 2015: 116). Deleuze sinemanın ilk yıllarındaki hareket imgenin propaganda olarak filme yerleştirildiğini ve kitleleri etkilediğini söylemiştir. Deleuze'e göre hareket imge özellikle 2. Dünya Savaşı' na kadar yoğun bir biçimde öne çıkmıştır. Deleuze bedenin sinemada bir imge olduğunu ve hareketin bedenin yanı sıra sinematografik unsurlarla kullanıldığını söylemiştir. İncelenen $L a L a$ Land filminde kamera açıları, müzik, kurgu gibi teknik imajlar ve doğrudan bedenin estetik hareketi anlam yaratmada etkili olmuştur. Film izleyicide duygulanım yaratmayı amaç edinmiştir. Sinema ile başlayan hareket imge sinemanın düşünce üretimi açısından katkı sağlamış ve bilincimizdeki imgeleri somut hale getirmiştir. Deleuze'un hareket imge kavramı modern müzikal filmlere bedenin estetik hareketi, kamera açıları, müzik ve montajla yansımıştır.

\section{Kaynakça}

Abisel, Nilgün (1995). Popüler Sinema ve Türler. İstanbul: Alan Yayıncıllk

Abisel, Nilgün (2014). Sessiz Sinema. Ankara: De Ki Basım Yayıncılık

Andrew, Dudley (2007). Sinema Kuramları. (Çev. İbrahim Şener). İstanbul: İzdüşüm Yayınları

Bazin, Andre (2013). Sinema Nedir?. (Çev. İbrahim Şener). İstanbul: Doruk Yayımcılık

Bordwell, David ve Thompson, Kristin (2009). Film Sanatı. (Çev. Ertan Yılmaz - Emrah Suat Onat). Ankara: De Ki Basım Yayım

Buckland, Warren (2013). Sinemayı Anlamak. (Çev. Tufan Göbekçin). İstanbul: Optimist Yayın

Cemalcılar, Ali (1993). "Filmde Müziğin, işlevi ve Kullanımı" Kurgu Dergisi S: 12. 73-79. 1993

Deleuze, Gilles (2004). Sinema I: Hareket imge. (Çev. Soner Özdemir). İstanbul: Norgunk.

Fischer, Ernst (1990). Sanatın Gerekliliği. (Çev. Çevat Çapan) Verso Yayıncılık, İmge Kitabevi

Kabadayı, Lale (2013). Film Eleştirisi. İstanbul: Ayrıntı Yayınları

Le Bon, Gustave (2014). Kitleler Psikolojisi. (Çev. Hasan Can). Ankara: Tutku Yayınevi

Monaco, James (2001). Bir Film Nasıl Okunur?. (Çev. Ertan Yılmaz). İstanbul: Oğlak Yayıncilık 
Öztürk, Serdar (2018). Sinema Felsefesine Giriş. Ankara: Ütopya Yayınları

Sözen, Mustafa (2017) "Anlatımsal Bir Öge Olarak Sinemada Ses Efektleri: Tanımlamalar, Filmler, Çözümlemeler." Akademik Bakış Dergisi Sayı: 61 Mayıs - Haziran 2017

Sütcü, Özcan Y1lmaz (2015) Gilles Deleuze'de İmge Hareketi Olarak Sinemanm Felsefesi, Bursa: Sentez Yayıncılık, 2.Bask1

Beaumont, Harry ( Yönetmen). (1929) The Broadway Melody [Sinema Filmi]. ABD

Crosland, Alan (Yönetmen). (1927). The Jazz Singer [Sinema Filmi]. ABD

Chazelle, Damien (Yönetmen). (2016). La La Land [Sinema Filmi]. ABD 